\title{
FURTHER EDUCATION OF ENGINEERING GRADUATES IN SOUTH AFRICA
}

\begin{abstract}
$\Delta \mathrm{N}$ examination of the qualifications of engineers in South Africa by Prof. (*. R. Bozzoli (S. Afr. J. Sci., 60, No. 12,1964 ) shows that in 1958 roughly 10 per cent of them held a higher degree, mostly in engineering, but a significant number in other fields, such as oconomies or idministrution. About half of them obtainod their higher dogrens in other countries, and it appeared that only about 5 per cent of the engineering graduntess in South Africa hold a rnaster's or a doctor's dogroo gained at a South African university. Disregarding the post-war ex-servicemen peak during 1948 and 1949 , tho average number of enrolmonts por annum of highor dogree candidates was about 50; the average number of higher dogrees awarded each year was 7.6 during tho six yoars 1950-56. Tho number of degroes awardod in engineering at the University of the Witwatersrand showed no upwards or downwards trend ovor a 23-year period, averaging $5 \cdot 2$ until 1957; thoro were 19 in 1962 and 22 in 1963.

The graduate of the past few years has been so stimulated by the intellectual excitemont of modern enginooring work that he has dovoloped the desire to broaden or deepen his knowledge by further study after graduation. This has also been made financially oasior by the small but significant number of bursaries and scholarships awarded for graduate study and research, particularly from the C.S.I.R. The more valuable scholarships, however, have boon tenable only in universities in other countries, mainly in Europe. So the pattern of the more able young South Africans leaving to pursue advaneed study and research oversoas is perpetusted. This in itself is good, but it has two unfortunate consequences, namely that the growth of graduate schools in South Africa is slowod down and a signifieant proportion of the ablest graduates never
\end{abstract} roturn.

A country such as South Africa, with an industry oxpanding oxplosively, and bocoming more dependent than before on her own resourees of matorial and manpower, essentially requires to oducato her best ongineors beyond the first dogreo. To do this she must have highly competent university engineering stuffs, she must solect her most outstanding graduntes for this odueation, and she must ensuro that theso gifted persons shall have completed their education at as early an age as possiblo in order that thoy may contribute fully to tho country's good. The first move should bo to ostablish a number of valuable scholarships of high prestige value, essontially for graduato study and research at a South African university, and for the bonofit of young people of proved high ability. The state should continue to provido undergraduate bursarios liberally for matriculants.

Assuming that finance can be arranged, there remains the noed to offer the kind of study and leadership and research that will be found attractive. It is porhaps natural in tho puro scioncos to attempt to achiovo this by setting up research facilities comparable with those in other countries. This sueceods in retaining somo of the best graduatos for a timo, but suffers tho disadvantage that many of them will be forced to emigrate sooner or later in the search for a permanent post of appropriate status. A similar policy in ongineoring is likely to be fatal, since permanent posts of a high status in acadernic research aro too few. What is neoded is interesting, modorn and woll-led study and rosoarch, at a lovol comparable with or oxcooding that offered in other countries, in topics which either promise to offer solutions to a national problom or altornativoly form part of a national projoct. The former is the field of the sociologist, the educationist, the geologist, geographer, geophysicist and others in tho humanitios and appliod seionens. Somo ongineering activitios also belong to this group, particularly mining, metallurgy and certain aspects of civil onginocring, but ever in theso branchos ono soos the best of the graduates boing kept for some special preparation prior to being launched into a study and research post elsewhere.

Fnginooring departments should give attention to the type of graduate work of which the Orange River Projoct is an outstanding oxamplo. Whothor tho main purpose is irrigation or water conservation or hydro-electric power generation, such a projoet can be of absorbing intorost not only to eivil engineers but also to land surveyors and to electrical and mechanical engineers as well, at both acadernic and applied enginooring lovels.

Prof. Bozzoli suggosts that rather than offering prospectivo Ph.D.s in engineering the narrow research topies the main value of which is the self-advancement of the individunl, South Africa should dircet its research efforts into projects conceived and directed at a national level.

\section{MODEL TESTING}

\begin{abstract}
A NUMBER of possible approaches is available to the civil and structural engineer to-day, onabling him to deal with a wide varioty of design problems for which solutions are required. According to Mr. R. E. Rowe, these include: (1) "A conventional approach basod on the theory of elusticity . . . considering only the service or working load conditions". (2) "An ultimato load approach based on considerations of the collapse of the structuro under loading conditions representing the service or working load conditions multiplied by an appropriate load factor." (3) "The application of computer"s to either of the two provious approwes which ... does enable much moro complox structures to be dealt with reasonably easily in
\end{abstract}

the design office." (4) "The use of modol analysis and testing as a dosign tool." This last approach was the themo of a one-day meeting held at the Royal Aeronautical Society, London, on March 17, 1964, organized by tho Comont and Coneroto Association, London, tho proceedings of which have now boen published as a separate volume (Model Testing, Cement and Concrete Association, London; pp. vi+58; Ostobor 1964. 25s.). "Model analysis and tosting roprosont an approach in which no simplifying assumptions need be made. . . . Furthermore, when usnd in its purest sonse, it does not resquiro prior knowledgo of the behaviour of any structural form; a physical model is made and tested, the behaviour is observed and from this 